ISSN 0853-8697

\title{
HIDROLISA ENZYMATIK PADA SERAT SELULOSA
}

\author{
Indah Molektuz Zuchairah \\ Konsentrasi Teknik Tekstil, Jurusan Teknik Kimia, \\ Fakultas Teknologi Industri, U niversitas Islam Indonesia \\ Jl. Kaliurang Km. 14 Y ogyakarta 55501, Telp. (0274) 895287, \\ Faks. (0274) 895007 ext. 148 \\ E-mail: Indah_mz@yahoo.com
}

\begin{abstract}
Sellulose material such as cotton, linen, ramie and viscose rayon fabrics al ong with a cotton/linen blend were hydrolyzed with cellulase from trichoderma viride. Surface fibrils were eliminated by 6 hour treatment in all cases. The loss of fibrillar matter appeared to be the primary cause of weight loss at this stage. On prolonged treatment, cotton, lines, and viscose rayon lost weight at a faster rate than ramie and the cotton/linen blend. The fall in yarn strength was progressive with increasing weight loss for cotton and viscose, while for linen and ramie it was slight initially and then increased sharply. Retention of strength after 46 hours incubation time increased in the order ramie<linen <cotton<viscose rayon. $X$ ray crystallinity and moisture sorption of the samples did not change after the treatment, indicating that the mechanism of endwise attack of the cellul ose at accessible cellul ose chain on crystallite surfaces appeared to apply to all four fibers. Changes in surface morphology could be followed for all enzymetreated fibers by scanning electron microscopy. Additionally mechanical tests demonstrated the changes in stretch ability and stiffness of the fabrics and the mobility of yarns within the samples.
\end{abstract}

Keywords: sellulole material, cotton, linen, ramie, viscose rayon

\section{PENDAHULUAN}

Salah satu teknik finishing kimiawi yang saat ini sedang dikembangkan di bidang pertekstilan adalah penggunaan enzyme. Penggunaan enzyme ini difokuskan untuk finishing kain cotton dalam rangka memperoleh kelembutan kain, dan untuk memperoleh kenampakan kain yang dapat mengikuti perkembangan mode, yang secara potensial mendukung kenyamanan pemakaiannya. Finishing dengan menggunakan enzyme merupakan teknik finishing yang tergolong sangat murah [1, 2, 3] namun memerlukan control proses yang optimal [4]. Metode dengan menggunakan enzyme cellulose ini dapat digunakan untuk menggantikan batu apung yang dimaksudkan untuk memperoleh efek stone washing pada proses denim yang sudah mapan [2, 3]. Konsep biolishing dengan menggunakan enzyme saat ini telah diperluas untuk struktur kain rajut dan kain serat campuran atau blended fabrics [5]. Saat ini bahkan penggunaan enzyme cellulase dicampur dengan ditergent [6, 7] dalam rangka untuk menghilangkan bulu-bulu kain sehingga dengan teknik ini warna kain menjadi semakin cerah.

Finishing dengan menggunakan enzyme cellulase pada material selulosa dapat meningkatkan kehalusan permukaan kain secara optimal, namun prosesnya harus dikontrol dengan baik agar penurunan kekuatan kain dapat dicegah. Proses 
yang dijalankan secara komersial memberikan pengurangan berat sampai mencapai sekitar 3-6\% akibat peristiwa hydrolysis, dan pengurangan kekuatan kain maksimum sampai mencapai $10 \%$, namun angka ini masih dapat diterima dalam rentang angka standar pengujian [5].

Mechanisme hydrolisa enzymatik pada material selulosa merupakan proses yang komplek dan belum diketahui secara menyeluruh [8, 9, 10]. Enzyme cellulase secara spesifik berfungsi sebagai katal is dan dapat memecah ikatan glokosida pada molekul serat selulosa sehingga menghasilkan formasi cellulase-substrat yang sifatnya komplek dan hebat. Persentuhan fisik secara langsung antara enzyme dan substrat diperlukan untuk terjadinya reaksi yang komplek [10]. Sisnergi dari perbedaan komponen-komponen pada struktur cellulase dan mekanisme inhibisi memberikan reaksi lanjut yang sangat komplek [11, 12, 13]. Reaksi dengan enzyme tergantung pada berat molekul dan metode penentuan, dimeter rata-rata

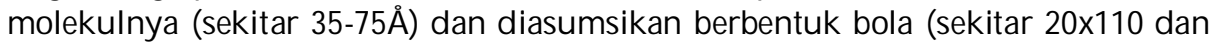
$40 \times 250 \AA$ ) yang diasumsikan berbentuk bulat panjang [14].

Secara komersial, finishing dengan menggunakan enzyme biasanya ditargetkan untuk kain cotton. Namun teknik finishing ini tidak dibatasi hanya untuk cotton, beberapa penelitian melaporkan bahwa finishing enzyme digunakan untuk serat selulosa lain seperti rami, rayon, dan lain-lain [15, 6]. Oleh karena itu tujuan utama pada penelitian ini untuk menentukan apakah penemuan-penemuan dari hasil penelitian yang telah dilakukan berlaku pula untuk serat selulosa seperti linen, ramie dan regenerasi sellulosa. Karena berdasarkan identifikasi komposisi kimia ada beberapa perbedaan yang nyata pada bentuk struktur dan morphologi dari serat-serat tersebut yang nantinya dapat menentukan rangkaian degradasi reaksi enzymatik. Linen dan rami merupakan struktur serat yang kristallinitasnya tinggi [16], dan puncak struktur spiralnya lebih rendah dibanding serat cotton. Perbedaan secara signifikan pada struktur inti dan ukuran kristallinitasnya juga sudah ditemukan [17]. Serat selulosa seperti linen dan ramie merupakan serat dengan sistem multiple sellular yang sangat jelas dibandingkan dengan serat cotton yang hanya terdiri dari single sel. Serat multisellular mengandung gum dan resin yang dapat menyatukan sel-sel serat [16]. Hal ini memungkinkan bahwa residu yang merupakan substansi penghalang tersebut dapat berpengaruh pada saat hidrolisa dengan enzyme. Disatu pihak, regenerasi selulosa merupakan system yang lebih simple dibandingkan serat selulosa alam. Kain rayon sebagaimana yang digunakan pada penelitian ini merupakan serat buatan dengan derajat polimerisasi rendah [18], kristallin [19] dan mempunyai derajat orientasi yang lebih baik dibanding serat cotton [19]. Tujuan lain pada penelitian ini adalah untuk menentukan secara kuantitas perubahan sifat mekanik kain setelah perlakuan dengan enzyme.

\section{EKSPERIMENTAL}

Spesifikasi kain yang digunakan pada penelitian ini disajikan pada Tabel 1. Kain blended cotton/ linen (52/48) tersusun dari benang cotton kearah pakan dan linen sebagai benang lusi. 
Kain ramie, telah difinishing dengan polyvinyl alkohol. Enzyme yang digunakan adalah cellulase dari jenis trichoderma viride (EC3.2.1.4) dengan aktifitas 9,0 units/ mg (Sigma chemical company). Enzyme cellulose jenis Trichoderma viride merupakan enzyme komplek dan banyak digunakan oleh para peneliti [14, 20, 21]. Semua zat kimia yang digunakan pada penelitian ini adalah reagent grade.

Tabel 1. Spesifikasi kain yang digunakan

\begin{tabular}{|l|c|c|c|}
\hline \multicolumn{1}{|c|}{ Jenis kain } & $\begin{array}{c}\text { Perbandingan benang } \\
\text { pakan/lusi per } \mathrm{cm}\end{array}$ & Berat kain $\left(\mathrm{g} / \mathrm{m}^{2}\right)$ & Tebal kain $(\mathrm{mm})$ \\
\hline $\begin{array}{l}\text { Cotton (bleached, desized, } \\
\text { anyaman polos) }\end{array}$ & $30 / 30$ & 108,15 & 0,286 \\
\hline $\begin{array}{l}\text { Saputangan linen } \\
\text { (anyaman polos) }\end{array}$ & $23 / 19$ & 83,86 & 0,225 \\
\hline Ramie(anyaman polos) & $24 / 23$ & 135,75 & 0,358 \\
\hline $\begin{array}{l}\text { Visose Satin (filament } \\
\text { cerah) }\end{array}$ & $66 / 24$ & 108,40 & 0,108 \\
\hline Blended cotton/linen & $24 / 18$ & 126,94 & 0,305 \\
\hline
\end{tabular}

Persiapan larutan enzyme; $1 \mathrm{~g}$ enzyme cellulase dilarutkan dalam $40 \mathrm{ml}$ larutan buffer ( $\mathrm{pH} 5,0)$ asam asetat. Kain dimasukkan dalam larutan pada liquor ratio 1:200 dan disetting pada suhu $37^{\circ} \mathrm{C} \pm 0,2^{\circ} \mathrm{C}$ selama 15 menit. Pada setiap g kain (telah dikondisikan) ditambahkan $4 \mathrm{ml}$ enzyme cellulase dan ditreatment dengan variasi waktu tertentu dengan gerakan teratur. Penentuan waktu reaksi dilakukan dengan cara kain dicuci dengan $100 \%$ aseton, yang kemudian diikuti dengan beberapa kali pencucian dengan air distilasi dan selanjutnya dikeringkan diudara. Prosentase hilangnya berat diperhitungkan dengan membandingkan berat kain sebelum dan sesudah treatment setelah kain dikondisikan $\left(65 \% \mathrm{RH}, 21^{\circ} \mathrm{C}\right)$. Kekuatan benang ditentukan dengan menggunakan Instron Tensile tester. Ketebalan kain dievaluasi menurut ASTM-D1777, sementara daya serap MR dievaluasi mengikuti metodeBuschle-Diller [12].

\section{HASIL DATA DAN PEMBAHASAN}

a. Pengaruh terhadap pengurangan berat kain

Data pada Tabel 2 merupakan hasil rata-rata pengujian prosentase hilangnya berat yang dilakukan terhadap 5 macam sample.

Tabel 2. Hilangnya berat sebagai fungsi waktu

\begin{tabular}{|l|c|c|c|}
\hline \multirow{2}{*}{\multicolumn{1}{c|}{ Jenis kain }} & \multicolumn{3}{c|}{ Hilangnya berat (\%) } \\
\cline { 2 - 4 } & 6 jam & 24 jam & 48 jam \\
\hline Cotton & 4,20 & 13,89 & 23,83 \\
\hline Linen & 6,34 & 13,59 & 21,13 \\
\hline Ramie & 3,80 & 6,44 & 10,46 \\
\hline Viscose Rayon & 2,46 & 13,63 & 26,23 \\
\hline Cotton/ linen blend & 4,58 & 8,90 & 15,69 \\
\hline
\end{tabular}


Kecepatan degradasi enzymatik kain selulosa tergantung pada beberapa faktor. Bentuk struktur serat memegang peranan penting yang sangat menentukan. Gambaran makroskopis seperti ketebalan kain dan konstruksi kain juga berpengaruh terutama untuk waktu treatment yang pendek. Untuk cotton, biasanya pada tahap pertama proses hidrolisis dapat menghilangkan permukaan fibril-fibril yang mengakibatkan pengurangan berat kain [5, 22]. Dengan lamanya waktu enzimologis dapat mengakibatkan kerusakan yang lebih serius dengan makin naiknya pengurangan berat kain dan selanjutnya dapat menyebabkan pengurangan kekuatan tarik kain [12].

Setelah 6jam waktu inkubasi, linen menunjukkan pengurangan berat yang paling tinggi, kemudian diikuti oleh cotton, ramie, dan rayon (Tabel 2). Alasan tingginya pengurangan berat pada linen ada hubungannya dengan konstruksi kain (anyaman polos), sehingga fibril-fbril pada permukaan benang lebih mudah dicapai oleh serangan enzyme. Konstruksi kain cotton juga anyaman polos, tetapi sedikit lebih padat sehingga pada awal proses dimungkinkan jalan masuknya enzyme sedikit tertahan. Alasan yang lebih tepat disebabkan karena banyaknya jumlah fibril pada permukaan benang yang mudah dicapai oleh enzyme. Setelah waktu inkubasi 48jam, pengurangan berat kain cotton lebih rendah dibanding linen. Jadi data ini menunjukkan bahwa pengurangan berat kain linen pada hakekatnya bukan karena linen lebih reaktif terhadap reaksi dengan enzyme dibanding cotton.

Secara umum, pengurangan berat kain ramie dapat dipertimbangkan lebih rendah dibanding serat yang lain (Tabel 2). Rami dikonstruksi dari benang tebal dibanding sample yang lain pada penelitian ini (Table 1) dan strukturnya relatif terbuka. Benang pakannya dilindungi oleh zat finishing polyvinyl alkohol, namun efek penyempurnaan ternyata tidak berpengaruh terhadap degradasi dengan enzyme, karena sample ramie lain (tanpa finshing) yang ditreatment dengan metode yang sama menunjukkan angka pengurangan berat yang sama. Alasan yang dapat direrima secara scientific mengapa ramie menunjukkan prosentase hilangnya yang rendah bila ditreatment dengan enzyme karena porositas rami lebih rendah dari cotton sehingga relatif lebih mudah akses dengan enzyme. Ladich [18] menyatakan bahwa ramie mempunyai pori-pori kurang dari 100 sampai $200 \%$ dari total volume dan area aksessibilitas permukaan yang rendah dibanding cotton. Ukuran pori-pori lebih memberikan kontribusi terhadap volume pori-pori pada kedua kasus tersebut, dan diameternya dapat diestimasi lebih rendah dari $200 \AA$.

Viscose rayon adalah serat yang paling sedikit terpengaruh oleh perlakuan dengan enzyme dalam waktu Gjam (Tabel 2). Namun dengan waktu 48jam, pengurangan beratnya lebih tinggi dari sample lain. Filament rayon sangat miskin dengan fibril sehingga akses dengan enzyme sangat sedikit dan hal ini merupakan alasan pada saat 6jam pertama pengurangan beratnya hanya sedikit dibanding serat yang lain. Tingginya pengurangan berat setelah 48jam waktu reaksi disebabkan karena tingkat kristallinitas dan derajat polimerisasi serat rayon yang rendah sehingga mudah terdegradasi. 
Untuk cotton/ linen blend pada 6jam waktu inkubasi menunjukkan tingkat pengurangan berat yang hampir sama dengan kain linen 100\% dan kain cotton $100 \%$ sebagaimana diharapkan pada penelitian ini. Dengan waktu reaksi yang lama, ternyata kain linen/ cotton blend menunjukkan nilai pengurangan berat yang rendah. Hal ini dimungkinkan karena pengaruh faktor makroskopis yang komplek seperti ketebalan dan konstruksi kain.

b. Pengaruh terhadap kekuatan benang/kain

Setelah 6 jam waktu inkubasi, terjadi penurunan kekuatan kain untuk semua sample. Rami sebetulnya tidak mengalami penurunan kekuatan (sangat sedikit). Setelah 24jam waktu inkubasi, kekuatan serat selulosa alam tinggal sekitar $50 \%$ lebih, sementara rayon viscose mengalami penurunan sekitar $60 \%$ lebih. Degradasi enzyme lebih lanjut dapat mengurangi kekuatan kain cotton lebih cepat dibanding linen atau rami.

Tabel 3. Kekuatan benang pakan dari kain (untreated) dan enzyme treated

\begin{tabular}{|c|c|c|}
\hline Jenis Sample & $\mathrm{BS}(\mathrm{N})$ & $\mathrm{RBL}$ \\
\hline Cotton; Untreated & 2,668 & 100 \\
6 jam & 2,345 & 87,9 \\
24 jam & 1,462 & 54,8 \\
48 jam & 0,755 & 28,3 \\
\hline Linen; Untreated & 5,238 & 100 \\
6 jam & 4,719 & 90,1 \\
24 jam & 2,933 & 56,0 \\
48 jam & 2,727 & 52,1 \\
\hline Ramie; Untreated & 6,681 & 100 \\
6 jam & 6,602 & 98,8 \\
24 jam & 3,836 & 57,4 \\
48 jam & 3,012 & 45,1 \\
\hline Rayon Viskosa; Untreated & 1,776 & 100 \\
6 jam & 1,472 & 82,9 \\
24 jam & 0,618 & 34,8 \\
\hline
\end{tabular}

Keterangan: $\mathrm{BS}=$ Breaking Strength, $\mathrm{BL}=$ Breaking Load (relatif)

Cotton dan rayon viskose keduanya tampak mengalami penurunan kekuatan yang nyata dengan bertambahnya prosentase hilangnya berat, sementara linen dan ramie pada awalnya tidak mengalami penurunan kekuatan yang nyata. Linen dan ramie banyak mengandung zat perekat yang porsinya tergantung pada kesuksesan proses prefinishing (seperti scouring) dan faktor ini diharapkan supaya porsinya rendah.

Setelah 48 jam waktu reaksi, ramie dan linen dapat mempertahankan prosentase kekuatannya yang signifikan tinggi dibanding cotton dan rayon viscose yang menunjukkan nilai kekuatan dengan nilai yang dapat diabaikan (Tabel 3). Linen mengalami pengurangan berat 2 kali lipat sample ramie setelah waktu 
reaksi 48 jam, merupakan fakta bahwa linen dapat menahan kekuatan sedikit lebih tinggi dibanding ramie. Hal ini memberi petunjuk bahwa kemampuan menahan beban per unit kain linen sedikit dipengaruhi oleh treatment enzyme dibanding dengan ramie.

Rendahnya daya tahan kekuatan dari cotton dimungkinkan disebabkan oleh lemahnya struktur serat. Bukti nyata adanya perubahan besar pada struktur serat cotton yang telah ditreatment dengan enzyme yang menunjukkan peristiwa daya menahan air dengan nilai yang signifikan tinggi. Nilai kekuatan rayon viskosa yang dapat diabaikan setelah waktu reaksi 48 jam dimungkinkan ada hubungannya dengan tingkat kristallinitas dan rendahnya derajat polimerisasi [12].

\section{c. Pengaruh kristallinitas dan aksesibilitas sample}

Hasil penelitian menyatakan bahwa kritallinitas, struktur inti, dan aksessibilitas permukaan internal substrat selulosa memegang peranan penting dalam reaksinya dengan enzyme cellulase [23, 10, 24]. Pengaruh factor-faktor tersebut ternyata tidak banyak mengalami perubahan atau hanya sedikit lebih tinggi setelah reaksi dengan enzyme [10, 25]. Tidak ada indikasi perubahan yang signifikan terhadap tingginya puncak grafik sample yang ditreatment dengan enzyme. Hasil penelitian menyatakann bahwa derajat kristallinitas dengan spectra infrared tidak banyak mengalami perubahan kecuali ramie sebagaimana ditunjukkan oleh data berikut [12].

Tabel 4: Pengaruh hidrolisa enzyme terhadap kristallinitas material selulosa [12]

\begin{tabular}{|l|c|c|}
\hline \multirow{2}{*}{ Tipeserat } & \multicolumn{2}{|c|}{ Index kristallinitas } \\
\cline { 2 - 3 } & Control (U ntreated) & Treated Enzyme \\
\hline Cotton & 0,87 & 0,87 \\
Linen & 0,87 & 0,87 \\
Ramie & 0,91 & 0,89 \\
Rayon Viskosa & 0,75 & 0,76 \\
\hline
\end{tabular}

Hal itu menunjukkan bahwa terjadinya serangan oleh reaksi dengan enzyme cellulase adalah terletak pada kemampuan aksessibilitas rantai selulosa yang selanjutnya bergabung secara komplek sebelum reaksi yang lebih hebat berlanjut pada rantai molekul berikutnya. Daerah amorf pada serat selulosa sering nampak sangat sempit untuk penetrasi molekul enzyme secara efektif, sehingga tidak ada perubahan ratio antara area yang teratur dan tidak teratur. Mekanisme reaksi yang terbukti dinyatakan teratur adalah regenerasi selulosa, cotton linter dan pulp kayu [26, 27], dan hal ini tidak berlaku untuk serat selulosa yang lain.

Tingkat ketidak teraturan serat selulosa dapat diestimasi dengan mengevaluasi data moisture regain, sementara kemampuan daya menahan air menunjukkan kapasitas menangkap air oleh pori-pori dan lumen dari serat. Tabel 5 menunjukkan nilai MR (moisture regain) dan WR (water retantion) dari beberapa sample. 
Tabel 5. Nilai (MR) dan (WR) dari sample

\begin{tabular}{|l|c|c|c|c|}
\hline \multirow{2}{*}{ Tipe Serat } & \multicolumn{2}{|c|}{ M oisture Regain } & \multicolumn{2}{c|}{ Daya M enahan A ir (WR ) } \\
\cline { 2 - 5 } & Control & $\begin{array}{c}48 \text { jam enzyme } \\
\text { treated }\end{array}$ & Control & $\begin{array}{c}48 \text { jam enzyme } \\
\text { treated }\end{array}$ \\
\hline Cotton & 6,51 & 6,33 & 45,75 & 56,57 \\
Linen & 6,99 & 6,66 & 53,47 & 54,27 \\
Ramie & 6,37 & 6,40 & 46,06 & 45,97 \\
Rayon Viskosa & 12,73 & 12,92 & 81,61 & 83,97 \\
Cotton/ linen blend & 6,74 & 6,66 & 43,07 & 55,10 \\
\hline
\end{tabular}

Sifat-sifat MR sample tidak berubah secara signifikan setelah treatment dengan enzyme. Hal ini mendukung hasil penelitian [8] yang menyatakan bahwa tidak ada kenaikan aksessibilitas enzyme pada area yang tidak teratur. Kemampuan serat menahan air juga menunjukkan nilai konstan, kecuali cotton/linen blended. Kapasitas dalam menangkap air untuk kedua sample tersebut bertambah sekitar $24-28 \%$, karena derajat kristallinitas sample tidak berubah secara signifikan, sehingga kita dapat berspekulasi bahwa kenaikan tingkat degradasi cotton merupakan alasan yang tepat dengan asumsi bahwa komponen cotton pada kain blended merupakan factor kontribusi yang menentukan. Alasan ini diperkuat oleh pernyataan beberapa penelitian bahwa serat cotton yang telah ditreatment dengan enzyme dan kemudian diwarnai menunjukkan warna yang lebih tua dibandingkan kain control [12]. Pernyatan ini juga didukung oleh data SEM dari serat setelah ditreatment dengan enzyme.

\section{d. Evaluasi SEM}

Bentuk morphologi sample yang telah ditreatment dengan enzyme cellulase menunjukkan terbebas dari bulu-bulu fibril terutama pada saat permulaan hidrolisa enzymatik, kemudian diikuti dengan retak pada arah spiral dan akhirnya permukaan serat menjadi mengelupas dengan bertambahnya waktu treatment (lihat Tabel 6).

Kain linen yang belum ditreatment dengan enzyme mengandung lebih banyak fibril yang terlepas dipermukaan serat dibanding dengan kain cotton yang belum ditreatment dengan enzyme. Selama 6 jam waktu inkubasi ternyata sangat efektif untuk menghilangkan fibri-fibril sehingga permukaan serat menjadi bersih. Dengan berlanjutnya reaksi hidrolisa menunjukkan adanya retak kearah aksial serat dan memberikan tanda kearah lebar serat dengan nyata. Setelah 48 jam waktu inkubasi, serat rusak membengkok dan kadang menunjukkan retak yang sangat dalam hingga hampir terpisah. Pecahnya serat linen (membengkok) dapat dipahami dan data membuktikan ternyata absorbansi terhadap air terutama terjadi di area ini dan zat-zat finishing dan zat warna sering terakumulasi [16]. Hal ini menunjukkan bahwa enzyme bereaksi dengan cepat pada daerah bengkokan dan degradasi terkonsentrasi pada daerah yang membengkok ini. 
Tabel 6. SEM berbagai serat

\begin{tabular}{|l|c|c|c|c|c|}
\hline $\begin{array}{l}\text { SEM serat } \\
\text { cotton }\end{array}$ & Sebelum ditreatment & Setelah hidrolisa enzyme \\
\hline
\end{tabular}

Perubahan bentuk morphologi rami sedikit lebih jelas setelah ditreatment dengan enzyme. Permukaan serat yang tidak mengalami hidrolisa menunjukkan sedikit fibril, dan setelah 6jam waktu inkubasi sama halnya dengan yang dialami oleh linen dan cotton. Degradasi lebih lanjut menunjukkan adanya sedikit retak pada sudut-sudut serat kearah aksial. Retak-retak ini terdistribusi secara tidak merata disepanjang sampel setelah ditreatment selama 24 jam. Makin lama waktu 
treatment menunjukkan makin dalam kerusakan serat. Keberadaan kondisi retak ini tidak terhalangi oleh adanya zat finishing polyvinil alkohol.

Rayon viskosa sebagai regenerasi selulosa sudah mempunyai permukaan yang halus. Bentuk asli serat rayon viskosa yang tidak ditreatment dengan enzyme tampak garis-garis kecil kearah panjang. Treatment dengan enzyme dalam hal ini menyebabkan permukaan serat sedikit kasar dan bentuknya mengedi, sedikit retak kearah aksial. Dengan waktu treatment selama 24 jam memberikan kerusakan yang tidak signifikan, dan setelah 48 jam sebagian filamen tampak kusut dan tertekuk bila dikontraksi. Pada kondisi ini sebenarnya serat patah kearah aksial. Namun, secara keseluruhan, kerusakan hanya terjadi sekali-sekali, sementara bagian utama dari benang masih tampak lengkap. Ini cukup mengejutkan karena pada tahap ini menyebabkan berkurangnya kekuatan sampai mencapai 95,9\%.

\section{SIMPULAN}

Hidrolisa enzymatik dapat mengurangi kekakuan, memberikan kekenyalan kain dan pada umumnya dapat merubah struktur kain dan hal ini terjadi pada semua kain yang berasal dari selulosa pada penelitian ini. Dengan waktu treatment yang pendek, kain cotton, linen dan ramie menunjukkan kecenderungan efek menghilangkan permukaan fibril-fibril tanpa menimbulkan hilangnya berat yang terlalu tinggi atau mengurangi kekuatan serat. Hubungan antara kekuatan serat dan prosentase hilangnya berat dari serat ramie dan linen berbeda dengan serat cotton dan rayon viskosa. Hasil SEM menunjukkan adanya perubahan morfologi struktur serat setelah mengalami degradasi enzymatik.

Indek kristallinitas sampel tidak berubah oleh pengaruh hidrolisa enzyme, juga tidak dapat memberikan akses terhadap nilai MR serat. Hal ini menunjukkan bahwa rasio kristallinitas serat terhadap area yang tidak teratur (amorf) dan tidak berubah dengan adanya degradasi enzymatik. Sehingga usulan mekanisme [24] bahwa serangan oleh enzyme cellulase terjadi pada daerah yang dapat akses dengan rantai selulosa di permukaan yang kristallin tampaknya berlaku pada serat selulosa selain serat cotton dan rayon.

\section{PUSTAKA}

[1] Kochavi, D., Videbaek, T., dan Cedroni, D. M. (1990) Optimizing Processing Condition in Enzymatic Stonewashing, A m. Dyest. Rep., Vol. 79, No. 2, 24-28.

[2] Olson, L. (1988) A New Technology for Stoneless Stone-Washing A pplication, A m. Dyest. Rep., Vol. 77, No. 5, 19-22.

[3] Tyndall, R. M. (1992) Application of Cellulase Enzymes to Cotton Fabrics and Garments, Textile Chem. Color., Vol. 24, No. 6, 23-26.

[4] Zuchairah, I. M. (1994) Monthly Progress Report, Ph. D. Thesis, UNSW.

[5] Pedesen, G. L., Screws, G. A., and Cedroni, D. M. (1992) Biopoleshing of Cellulosic Fabrics, Can. Textile J., Vol. 109, 3135.

[6] Lymann, P. (1990) Promising New Markets Emerging for Commercial Enzymes, Chem. Eng. N ews, Vol. 10, 17-18.

[7] Mycumbar, S. G. (1993) P\&G Ditergent Development Cheer-ed on by Cotton Inc., D aily N ews Rec., No. 2, 2-3. 
[8] Finch, P., dan Robert, J. C. (1985) Enzymatic Degradation of Cellulose, dalam Nevell, T. P., dan S. H. Zeronian, eds., Cellulose Chemistry and its Application, John Wiley and Sons, NY, 312-343.

[9] Goyal, A., Gosh, B., dan Eveleigh, D. (1991) Characteristic of Fungal Celluleses, Bioresourse Technol., Vol. 36, 37-50.

[10]Walker, L. P., and Wilson, D. B. (1991) Enzymatic Hydrolysis of Cellulose: An Overview, Bioresource Technol., Vol. 36, 3-14.

[11] Bhattawdekar, S. P., Sreenivasan, S., Balasubramaya, R. H., dan Paralikar, K. M. (1992) Effect of an Alkali Treatment on the Enzymolysis of Never Dried Cotton Cellulose, Textile Res. J., Vol. 62, 290-292.

[12] Buschele-Diller, G., Zeronion, S. H. (1995) Enzymatic and Acid Hydrolysis of Cotton Cellulosa after Slack and Tension Mercerization, Textile Chem. Color.

[13]Puri, V. P. (1984) Effect of Cristallinity and Degree of Polymerization of Cellulose on Enzymatic Saccharification, Biotechnol. Bioeng., Vol. 26, 1219-1222.

[14] Bengheim, L. E. R., Petterson, L. G., dan Axio-Fredriksson, U. B. (1976) The Mechanism of Enzymatic Cellulose Degradation, Eur. J. Biochem., Vol. 61, 621-630.

[15] Anonymous (1991) Putting Polish on Cotton Fabribc, Cotton Grover, Vol. 27, 20-21.

[16] Batra, S. K. (1985) Other Long Vegetable Fibres, dalam Lewin, M. dan Pearce, E. M., eds., Handbook of Fibre Science and Technology, Vol. 4: Fibre Chemistry, Marcel Dekker Inc., NY, 727-807.

[17]Ladisch, C. M., Yang, Y., Velayudhan, A., dan Ladisch, M.R. (1992) A New Approach to the Study of textile Properties with Liquid Chromatography, Textile Res. J., Vol. 62, 361-369.

[18] Lundberg, J., dan Turbak, A. (1982) dalam "Kirk-Outmer Encyclopedia of Chemical Technology, Vol. 19, 1982, 855-880.

[19]Hermans, P.H. (1949) Physics and Chemistry of Cellulose Fibers, Elsevier Publishing Co. Inc., NY.

[20]Cowling, E. B., dan Brown, W. (1969) Celluloses and Their Application, Adv. Chem. Ser., Vol. 95, 152-187.

[21] Finch, P., dan Robert, J. C. (1985) Enzymatic Degradation of Cellulose, dalam Novel, T. P., dan Zeronian, S. H., eds., Cellulose Chemistry and Its A pplication, John Wiley and Sons, NY, 312-343.

[22]Tyndall, R. M. (1992) Application of Cellulase Enzymes to Cotton Fabrics and Garments, Textile Chem. Color., Vol. 24, No. 6, 23-26.

[23] Focher, B., Marzetti, A., Beltrame, P. L., dan Carniti, P. (1991) Structural Features of cellulose Derivative and Their Effect on Enzymatic Hydrolysis, dalam Haigler, C. H. dan Weimer, P. J., eds., Biosynthesis and Biodegradation of Cellulose, Marcel Dekker, NY, 293-310.

[24]Weimer, P. J. (1991) Quantitative and Semiquantitative Measurements of Cellulose Biodegradation, dalam Heigler, C. H. dan Weimer, P. J., eds., Biosynthesis and Biodegradation of Cellulose, Marcell Dekker, NY, 263-291.

[25] Wood, T. M. (1991) Fungal Cellulases, dalam Heigler, C. H.,dan Weimer, P. J., eds., Biosynthesis and Biodegradation of Cellulose, Marcell Dekker, NY, 491-525. 